\title{
Parental 'Consent' to Child Removal in Stolen Generations Cases
}

\author{
Thalia Anthony and Honni van Rijswijk
}

\section{Introduction: The problematic of consent in legal narratives}

Consent, will and agency have problematic uses in the law. ${ }^{1}$ Subjected groups are implicitly inferiorised through these concepts, such that their complicity to acts of the subjector is taken for granted. This complicity, Sadiya Hartman asserts, shrouds the 'condition of violent domination' that actually operates between subjector and subjected. ${ }^{2}$ Writing about the legal context of racial subjugation during slavery and its aftermath in the United States of America, Hartman argues that consent became 'intelligible only as submission'. ${ }^{3}$ In the Australian context, according to Ghassan Hage, non-'whiteness' has historically been a point of reference for structural inferiority. ${ }^{4}$ Yet, the law nonetheless assumes consent as capable of being equally afforded by 'blacks' and 'whites'. The historical impossibility of consent in the context of forced subjection is usually not disentangled, explored, or even 'seen' by the courts.

In Stolen Generations cases, the subject of this chapter, assumptions that 'whites' could better care for children underlie the implication of complicity in the removal of children from Aboriginal ${ }^{5}$ guardians. These assumptions were taught to and at times appropriated by Aboriginal parents - who were then seen as succumbing to the system's logic. ${ }^{6}$ As Hartman suggests, power can become defined by these manipulations to present a picture of reciprocation, rather than

\footnotetext{
1 Sadiya V. Hartman, Scenes of Subjection: Terror, Slavery, and Self-Making in Nineteenth-Century America (New York: Oxford University Press, 1997), 40.

2 ibid., 85.

3 ibid.

4 'Whiteness' is a cultural historical construct (Ghassan Hage, White Nation: Fantasies of White Supremacy in a Multicultural Society (Sydney: Pluto Press 1998), 58-59), which involves 'both a European monopolisation of "civilised humanity" and a parallel monopolisation of Whiteness as its marker' (Hage, Against Paranoid Nationalism: Searching for Hope in a Shrinking Society (Sydney: Pluto Press, 2003), 49-50).

5 The term 'Aboriginal' rather than 'Indigenous' is used throughout the article, excepting quotes from other sources. While Torres Strait Islanders also experienced child removal, the cases discussed in this article are based on mainland Aboriginal people. The term 'Aboriginal' is also used because it is consistent with the term referred to in the legislation and cases that constitute the basis of this article.

6 Hartman, 88.
} 
acts of domination. ${ }^{7}$ The agency of the dominated in providing consent 'secures the fetters of subjection, while proclaiming the power and influence of those shackled and tethered'. ${ }^{8}$ It allowed the state to be presented as a benevolent institution rather than a terrorising one. There is, however, a further sinister side to the domination, which is always on guard when manipulations falter. When parents failed to comply with the removal of their children, they would attract reprisals from state agents - with consequences that included being reported to police, losing employment or experiencing physical violence. ${ }^{9}$ Hartman challenges the possibility that 'will' means anything when operating in such a state of subjection, because it is 'unrecognizable in a context in which agency and intentionality are inseparable from the threat of punishment' ${ }^{10}$ As Hartman explains in relation to the ability of slaves and ex-slaves in the United States to meaningfully consent to sexual activity, "The issue of consent is framed by the law's negation of the captive will and the violent domination of slave relations'.11

Our reading of recent Stolen Generations cases, described below, argues that courts prior to Lampard-Trevorrow ${ }^{12}$ treated consent as an individual act, freely and voluntarily given by a liberal subject. These readings are based on the texts of the judgments, rather than on analyses of the processes by which the texts were created - through the choice and shaping of facts, and the interpretation of evidence - which is the subject of research by Trish Luker. ${ }^{13}$ Consent was seen as a legitimate factor that duly activated the powers of the legislation to bring about legal removal, according to Justice Maurice $\mathrm{O}^{\prime}$ Loughlin in Cubillo. ${ }^{14}$ In the previous Stolen Generations case of Williams, formal consent had barred false imprisonment and trespass on the basis that a child cannot be imprisoned if her mother consented to the removal. ${ }^{15}$ This chapter goes further than simply suggesting that Aboriginal consent has been misread by the courts - which was clearly the situation until the case of Lampard-Trevorrow. It also proposes that consent was, and is still used in an underhanded way by the state to legitimise its actions and protect itself from liability. After all, most statutory creatures governing the Stolen Generations allowed for removal, irrespective of consent.

7 ibid., 89.

8 ibid.

9 National Inquiry into the Separation of Aboriginal and Torres Strait Islander Children from Their Families, Bringing Them Home: Report of the National Inquiry into the Separation of Aboriginal and Torres Strait Islander Children from their Families (Sydney: Human Rights and Equal Opportunity Commission, 1997), 6, 8, 56.

10 Hartman, 85-86.

11 ibid., 105.

12 State of South Australia v Lampard-Trevorrow [2010] SASC 56.

13 Trish Luker, 'Intention and Iterability in Cubillo v Commonwealth', Journal of Australian Studies 84, no. 1 (January 2005): 35-41.

14 Cubillo v Commonwealth of Australia (2000) 174 ALR 97, 262.

15 Williams $v$ The Minister, Aboriginal Land Rights Act 1983 and Anor [1999] NSWSC 843. This finding was upheld on appeal: Williams $v$ The Minister Aboriginal Land Rights Act 1983 and New South Wales [2000] NSWCA 255. 
The state, nonetheless, sought to procure consent in order to rationalise the policy, facilitate removals, and shift the responsibility for removal from the state to Aboriginal parents.

The use of consent in this way turned the state's act of removal into a parental act, thereby transforming 'relations of violence and domination into those of affinity' ${ }^{16}$ It suggests that the powerless had agency and strength, and that there is an 'ostensible equality between the dominant and the dominated', ${ }^{17}$ while at the same time concealing the actual powerlessness of the subjected. The fiction of consent suggests that Aboriginal people were placed in the same situations as, and had the same range of options available to, white people. Judicial narratives have mostly failed to illustrate the 'limited possibilities, constraint, despair, and duress ${ }^{\prime 18}$ that are masked by this narrative of consent. Further, the use of consent in organising child removal imputes that Aboriginal peoples are unwilling to care for their own children, and reaffirms the fiction that the caring and nurturing of children is the domain of 'whites', thereby undermining the role of the Aboriginal family. But, here, there is a further irony - that Aboriginal consent is predicated on the presumption of civility, and yet Aboriginal people are denied this virtue because of their role as neglectful parents.

\section{Historical narratives in Stolen Generations cases}

Historical narratives of the Stolen Generations in the 1997 report Bringing them Home revealed the hollow meaning of parental consent in child removal. Consent was often coerced and rarely informed. It was a veil for the forced removal of Aboriginal children. A Tasmanian Stolen Generations survivor described his mother's capacity to consent in the following way: '[Mum] could not read or write, and obviously would not have understood the implications of what she was signing'. ${ }^{19}$ The report found that 'mothers who had just given birth were coerced to relinquish their newborn babies ... The Child Welfare Department did not check to ensure that Indigenous mothers understood they were being asked to agree to the permanent removal of their child'. The report identified that acquiring consent operated to circumvent official proof of neglect. Bringing them Home noted, 'If parents could be "persuaded" to consent to the removal of their children the Board did not have to show that a child was neglected or uncontrollable' ${ }^{20}$ When indigenous parents refused to consent, the Aboriginal

\footnotetext{
16 Hartman, 88.

17 ibid.

18 ibid., 104.

19 National Inquiry, 86, quoting 'Confidential evidence 384, Tasmania'.

20 National Inquiry, 40.
} 
and Welfare Boards overpowered their agency. Parents 'were told they would have to leave the stations and would be denied rations' ${ }^{21}$ Police officers told young mothers that if they did not consent to the adoption of their babies the father of the child would be prosecuted for carnal knowledge' ${ }^{22}$ Alongside this was an ideological campaign to make parents feel guilty that they could not offer their children the opportunities of the 'outside world' ${ }^{23}$ This is despite contemporary evidence and theory that children who were not removed performed much better in life than those who were removed.

The issue of parental consent for the removal of Aboriginal children has been central to cases involving compensation for injuries arising out of the removal of Aboriginal children. In Williams (1999), ${ }^{24}$ consent was key to whether Joy Williams's removal at birth constituted false imprisonment; in Cubillo (2000), ${ }^{25}$ consent was not determinative to claims in negligence due to the broad scope of the statute granting the Welfare Board powers to remove children, but was nonetheless argued in defence by the government and, in the 2007 trial case of Trevorrow, ${ }^{26}$ and the 2010 Appeal case of Lampard-Trevorrow, ${ }^{27}$ consent was discussed both in relation to negligence and false imprisonment. Consent has been a central issue in Stolen Generations cases for two main reasons: first, it formed part of the factual archive due to the widespread practice of officials seeking parental consent to expedite the process of removal; and second, the state has used parental consent to bar actions in trespass or false imprisonment. Therefore, the procurement of consent has had a doubly wicked effect, because it was used to justify expedient removals and was subsequently put as a legal justification to deny compensation on the basis that the mother had given away her child.

Before the most recent Stolen Generations case of Lampard-Trevorrow (the first in which compensation was awarded), cases dealt inadequately with the historical operation of consent. In Lampard-Trevorrow, parental non-consent was important to both the factual and legal findings. Factually, the court found no consent had been given. Legally, non-consent became central to the court's interpretation of the state's failure to properly execute its statutory authority and assume control of Bruce Trevorrow, at the age of 13 months, without parental consent. We will argue that, in Lampard-Trevorrow, the court demonstrated a much more nuanced understanding of the operation of consent in historical

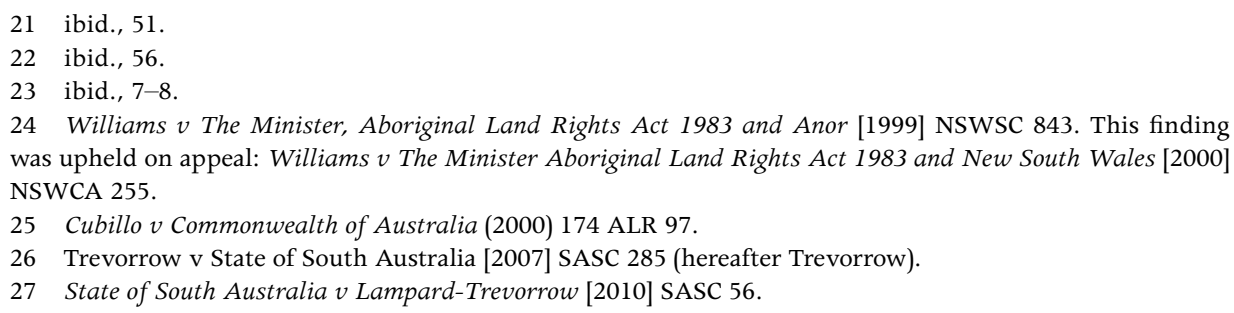


circumstances, with mixed results. On one side, there was a departure from the earlier case of Cubillo in which a formalist reading of consent was ultimately accepted, and this departure allowed for a finding of negligence on the part of the state. The Appeal Court in Lampard-Trevorrow, however, did not go so far as to provide a finding in false imprisonment, continuing the courts' ahistorical reading of consent in the context of that legal issue. The court's approach in Lampard-Trevorrow is not unproblematic, and a key question we ask relates to the case's potential: does Lampard-Trevorrow provide a productive alternative and counter-narrative to past uses of consent in Stolen Generations litigation, or is it in fact traversing the same path as other litigation, where recognition depends on the existence of 'lucky' or atypical facts fitting within the dominant narrative, and which benefits a small number of survivors, while at the same time excluding many others?

\section{Issue of consent in statutory interpretation: Taking the high ground in Cubillo}

One of the first cases brought by a Stolen Generations survivor was Cubillo and Gunner $v$ The Commonwealth in 2000. ${ }^{28}$ Here, the Federal Court, presided over by Justice $\mathrm{O}^{\prime}$ Loughlin, ultimately failed to acknowledge that the production of parental consent to child removal, which involved practices of bluff or deception on the part of the state, had any legal effect, despite the acceptance of evidence that established these practices as a matter of fact. The first plaintiff in this case, Lorna Cubillo, was born in 1938 and, at the age of seven, was forcibly removed by the Aborigines Inland Mission and the Native Affairs Branch to Retta Dixon Home in Darwin, where she remained until she was 18 years old. The second plaintiff, Peter Gunner, was born in 1948 on a pastoral station and was removed when he was about seven years old to St Mary's Church of England Hostel in Alice Springs. He remained there until he was 16 years of age. Before he was removed in 1956, the trial judge described him as having been 'part of a happy, healthy Aboriginal community and environment at Utopia Station' ${ }^{29}$ The issue of consent to removal was at the heart of the Commonwealth's legal argument against Lorna Napanangka Cubillo and Peter Gunner. Essentially, the Commonwealth sought to recharacterise the act of removal as consensual and thereby authorised by the parents. In Cubillo's case, the court found that the issue determining legislative authority to remove her under s. 6 of the Aboriginals Ordinance was not one of consent. Rather, it was whether the director of Native Affairs held the opinion that it was 'necessary or desirable' to

28 Cubillo v Commonwealth of Australia (2000) 174 ALR 97 (hereafter Cubillo).

29 ibid., 98. 
undertake her 'care, custody or control' ${ }^{30}$ Ultimately, the court acknowledged that the director properly used his authority under the legislation. In Gunner's case, it was found that questions relating to consent, were not the 'correct question[s] to ask' in legally characterising the act of removal - rather, the key question was 'the reason for his removal' — so that 'it would not matter by what persons or by what means that removal was effected, if his removal was effected within the terms of ss 6 or 16 of the Aboriginals Ordinance'. ${ }^{31}$ Nonetheless, parental consent was one factual matter that was taken into account in assessing whether the legislation had been properly applied. In referring to consent in his construction of compliance with s. 6, O'Loughlin J noted that 'there was no way of knowing whether the thumb mark on the "Form of Consent" was [Mr Gunner's mother's]; even on the assumption that it was, there was no way of knowing whether [she] understood the contents of the document'. ${ }^{32}$ However, the court gave the government officers the benefit of doubt:

But it is not beyond the realms of imagination to find that it was possible for a dedicated, well-meaning patrol officer to explain to a tribal Aboriginal such as [Mr Gunner's mother] the meaning and effect of the document. I have no mandate to assume that [Mr Gunner's mother] did not apply her thumb or that she, having applied her thumb, did not understand the meaning and effect of the document. ${ }^{33}$

Therefore, the documentary record was found to prevail over the context in which Aboriginal parents were made to give their consent for their children to be taken.

On his way to finding that the issue of consent did not go 'to the heart' of the trial, ${ }^{34} \mathrm{O}^{\prime}$ Loughlin $\mathrm{J}$ rejected submissions made on behalf of the Commonwealth that some or all of the parents had initiated their children's removal by asking the Native Affairs Branch or Aborigines Inland Mission to provide their children with a better education and better standard of living. ${ }^{35}$ The court found that evidence did not establish consent was generally obtained by the Native Affairs Branch in the removal of the children at Phillip Creek, of whom Cubillo was one. ${ }^{36}$ Although making no formal finding on the matter, he found that the evidence (including the behaviour of the mothers, the evidence of three Tennant Creek women and the limited time available to explain the process of removal) suggested that 'some, if not all, of the children may well have been taken without

\footnotetext{
ibid., 262, 263.

ibid., 352.

ibid., 344.

ibid.

ibid., 262.

ibid., 263.

36 ibid., 251.
} 
their mothers' consent' ${ }^{37}$ In fact, he was 'unable to make a finding that any of the mothers gave their informed consents to the removal of their children' ${ }^{38}$ Therefore, the judge rejected the Commonwealth's argument that consent had been generally given. Where there was documentary evidence of a thumbprint, however, he favoured the assumption that consent was informed, as in the case of Gunner's mother Topsy. Although the court demonstrated an appreciation of historical context, it was not applied to interpreting legal sources.

It is significant that the court examined the operation of consent more generally than the circumstances surrounding the particular plaintiffs, and demonstrated that 'consent' was not an untroubled concept. O'Loughlin J questioned the nature and quality of consent, and the power relationship that produced consent, by referring to evidence that showed that the practices of the director in obtaining consent included processes of 'educating and preparing mothers' for separation. ${ }^{39}$ The implication here, of course, is that any final and formal consent can be seen as an end-effect of these processes of 'education'. O'Loughlin $\mathrm{J}$ questioned whether sufficient consent can be deemed to have been given by parents, considering the stringent time constraints under which the information was purportedly provided..$^{40}$

Ultimately, however, the courts found that the documents reflected Topsy's informed consent. It took for granted that the relevant information was given in the correct language, and the effectiveness of a government education program in relation to removals. We will see later that, in Lampard-Trevorrow, the South Australian Court of Appeal, by contrast, expressed a distrust concerning the documentary record regarding consent, and used a practice of interpretation that considered general practices relating to consent (and its documentation) in evaluating the particular document at issue. In Cubillo, consent was made central to the narration of separation, as well as to the legal characterisation of this moment but, despite the fact that parental consent was discussed at length in the proceedings, it was rejected as a determining factor in law: it is a factor very much present in the text, but it ultimately appears in excess to the legal reasoning. It is thereby located strangely in the text, as a kind of haunting authority: the court found it impossible to narrate the separation of child from parent, or child from community, without considering the reactions of these parties; and the main way in which these reactions might matter in law is through the concept of consent. And yet, because these relationships are held to have no legal significance, the court told the story of this deeply problematic consent and then put that story aside.

37 ibid., 265.

38 ibid., 251, emphasis ours.

39 ibid., 179.

40 ibid., 265. 


\section{History meeting law in Lampard-Trevorrow}

In 2010 the South Australian Court of Appeal in Lampard-Trevorrow ${ }^{41}$ upheld a decision in 2007 to award Bruce Trevorrow over half a million dollars in compensation for the injuries he suffered following his removal from his family as a child. It was the first successful claim by a Stolen Generations litigant. The court's reasoning revealed a different historical reading of the facts and the policy context of the Stolen Generations from earlier cases. The finding of non-consent of his parents was fundamental. It enabled the court to portray the removal as forced and provided a basis for a breach of law. Therefore, not only was there forcible removal, but it was legally wrong.

The decided facts in Lampard-Trevorrow are that Trevorrow was taken by the Aborigines Protection Board (APB), without the consent of his parents, at the age of 13 months, while he was in hospital. The trial judge found that neither Joseph Trevorrow nor Thora Karpany, the natural parents, knew about or consented to the placement of Bruce Trevorrow with the Davies family. The court found that it was the state's failure to acknowledge the parents' authority (and therefore the lack of consent to Trevorrow's removal) that led, in part, to the state's liability. Unlike Cubillo, the court of appeal did not find that the ultimate authority concerning Trevorrow's removal lay elsewhere, such as with a statutory authority. The court found that s. 10 of the Aborigines Act 1934 (SA), which provided that the APB was 'the legal guardian of every Aboriginal child' was ambiguous. It found that the legislation did not abrogate fundamental rights in the absence of the manifestation of a clear intention to do so. Therefore, s. 10 did not give the APB the power to foster an Aboriginal child without the consent of the child's parents.

\section{Issue of consent in Lampard-Trevorrow}

The state of South Australia submitted that the trial judge was wrong to find that neither parent consented to Bruce Trevorrow's placement with Mrs Davies, and here it relied mainly on missing documentation concerning the removal. The court of appeal acknowledged that documents were missing, but found that consent had not been given - significantly, in doing so, it relied on evidence concerning general practices concerning consent, as well as evidence concerning Trevorrow's particular case. While the court in Cubillo referred to similar general practices, its finding in relation to Gunner's mother's consent was based on the documentary evidence alone. The significance of the court's interpretation in Lampard-Trevorrow is that it is an acknowledgment of the

41 State of South Australia v Lampard-Trevorrow [2010] SASC 56 (hereafter Lampard-Trevorrow). 
importance of context in the historical operation and legal interpretation of consent. It is significant that the court of appeal was willing to look critically at documents presented as evidence, and did not interpret the absence of documents as necessarily favouring the state's position. The court rejected the state's submission concerning a particular missing file, that it may have contained the records of the almoner testifying to the consensual removal of the plaintiff, arguing that the time constraints and role of the almoner made it unlikely that the records would include a document concerning consent. ${ }^{42}$ On the question of privileging documentary evidence, the court held:

There is no reason why, in principle, the documentary records should be preferred to the oral evidence. Everything depends upon the facts of the case. In the present case it needs to be borne in mind that documentary records are not to be assumed to be reliable. ${ }^{43}$

Based on an analysis of correspondence concerning other cases, the court found that 'the requirement to obtain parental consent was not always observed' ${ }^{44}$ The court based this conclusion on a number of documents. A letter dated 12 August 1958, from the secretary of the APB to the officer in charge at the Oodnadatta Police Station, stated:

If the parents of these children have not already consented in writing for the United Aborigines Mission to care and control the children until a certain age, then I suggest that you endeavour to obtain the consent of the parents on the forms enclosed.

In confidence, you will certainly realise that in any case this consent form is not a legal document, and should it be that the parents remove the children from the care of the Mission or the Board, no legal action could be taken to regain control of the children. ${ }^{45}$

Another document, a letter of 16 October 1958, written by the secretary of the APB to the superintendent of Aborigines welfare in Victoria, stated: Again in confidence, for some years without legal authority, the Board have taken charge of many aboriginal children'. ${ }^{46}$ In a letter dated 19 May 1960, to Pastor Eckermann, the secretary of the APB stated: 
For your information only I have to inform you that legally, I have no right to remove a child from its parents. However, in such cases I do so and where deemed necessary we refuse to allow the child to be returned to its' [sic] parents without my consent.

If you so desire you can inform the mother of the child that it has been placed in your Children's Home at my direction and cannot be released to the mother without my written consent. You should add that I will not likely consent to the children being released until such time as the mother is properly accommodated and able and willing to care for the child in a proper manner. ${ }^{47}$

Here the court concluded:

the Secretary of the APB is informing Pastor Eckermann, 'off the record' that on occasions he has removed and will remove a child from its parents, without parental consent, and will subsequently refuse to allow the child to be returned to the parents, unless satisfied that the proposed living arrangements are suitable. ${ }^{48}$

The last paragraph quoted above 'contemplates a bluff being used to enable the APB to keep the child in question under its control' ${ }^{49}$

It is in the context of this understanding that the court of appeal read a letter the APB sent to Thora Karpany in 1958, which was prepared in response to her inquiry about Bruce. The letter stated that Bruce was still undergoing medical treatment, and the court found this statement, and the implication that Bruce could therefore not be returned to her, 'dissembling'. ${ }^{50}$ Even if Thora Karpany had consented to Bruce Trevorrow being fostered, such consent did not legally authorise Bruce's permanent removal - and the secretary of the APB knew of Thora's entitlement to have Bruce returned to her. Here we have the court explicitly acknowledging the problematic role of consent in the practice of removal - problems that were intimated in Cubillo, but which in LampardTrevorrow are labelled as 'a pretence of power' ${ }^{51}$

Although the appeal court acknowledged the possibility that consent was obtained 'by one of the now unavailable witnesses, and ... placed in one of the missing files', the court found that the trial judge's conclusion of non-consent

\footnotetext{
7 ibid., 128.

48 ibid.

49 ibid.

50 ibid., 126.

51 ibid., 133.
} 
was supported by significant evidence. ${ }^{52}$ First, there was no documentation of consent in Bruce Trevorrow's file. Second, there was no reliable reference to consent being given in other documents. Third, there was evidence that:

when necessary, in the perceived interests of a child, the [Board] would place a child in an institution or with a foster family without parental consent, using a pretence of power (which undoubtedly would have been effective) and, if appropriate, using an element of bluff or deception. ${ }^{53}$

This last point is significant since here, the South Australian Court of Appeal referred to the general context of practices and policies in which consent was made - taking a very different approach to interpretation from that used in Cubillo, where the Federal Court noted the evidence of general policies but, in making its findings, insisted on narrowing its focus to the particular circumstances of the applicants. ${ }^{54}$ In contrast, the court of appeal found that, 'The reliance on medical advice in response to Thora Karpany's letter to the [Board] of 25 July 1958 is consistent with the use of a bluff to deflect her request ${ }^{\prime} .^{55}$

\section{Changing approach to false imprisonment: Turn from Williams}

Consent was a central issue in the claim of false imprisonment in the first Stolen Generations case, Williams v Minister, Aboriginal Land Rights Act 1983, brought before the New South Wales Supreme Court in $1999 .{ }^{56}$ False imprisonment is committed when someone 'directly subjects another to total deprivation of freedom of movement without lawful justification [or consent] ${ }^{57}$ It is a powerful avenue for Stolen Generations litigants because it does not depend on the government acting negligently or breaching a statute. Rather, it arises because the plaintiff has his or her liberty restricted.

The facts of the Williams case were that Joy Williams was removed immediately after her mother had given birth and while being treated in hospital. Joy had stayed in children's homes until she was 18 years old. She was removed under s. 7(2) of the Aborigines Protection Act 1909 (NSW), which gave the Aborigines Welfare Board the power to take Joy under circumstances where the mother

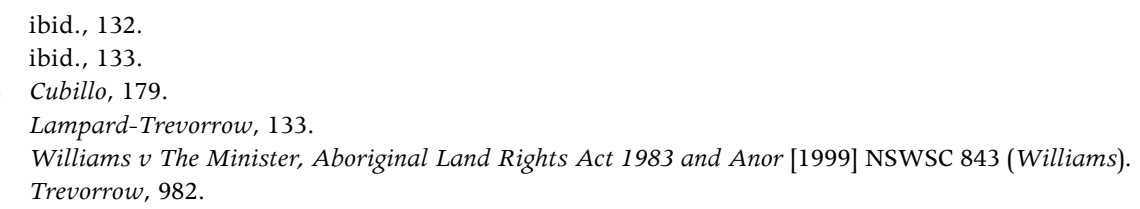


consented. She claimed that the removal caused her physical and psychological harm and she brought a number of claims. However, it was false imprisonment in which the issue of consent was at the forefront.

The New South Wales Supreme Court emphasised the mother's consent to removal at the time of the birth of her daughter, although this was contested by Joy, and ruled against false imprisonment on that basis. ${ }^{58}$ The court stated that there was no false imprisonment because the welfare board 'had lawful control over the plaintiff' due to the consent of the mother. ${ }^{59}$

In reviewing the case, the New South Wales Court of Appeal adverted to the problematic nature of consent, but chose to treat consent as proven by virtue of the documentary evidence of the application. The court held:

One part of the plaintiff's case at trial depended on the proposition that she had been removed from her mother without her mother's consent. It was this which underlay the claims of false imprisonment ... This part of the case failed because ... the plaintiff was lawfully admitted to the control of the Board on the application of her mother..${ }^{60}$

The nature of the evidence of consent, and how consent was acquired, has been questioned by academics and legal practitioners. Anna Cody, who was a solicitor on the case, commented that Joy Williams 'was taken away from her mother when she was a few hours old. Any mother who's had a baby would question exactly how much she could consent to giving a baby away when she's just a few hours old' ${ }^{61}$ Chris Cunneen and Julia Grix argue that the court's comment that the mother may have forgotten whether she had consented reveal an 'extraordinary lack of insight into the issues of consent and the power of the [Board] over Aboriginal persons' ${ }^{62}$

Another issue that was raised by the New South Wales Supreme Court to inculcate the mother in the removal was that the mother did not attempt to

58 The Supreme Court relied on s. 7(2) of the Aborigines Protection Act 1909 provided: 'The board may on the application of the parent or guardian of any child admit such child to the control of the board' Williams, [26].

59 Williams, [142]. The court stated, 'My finding is that the AWB considered the mother's application to give up control of the plaintiff to its control, and having done so, admitted the child to its control. I find that there was not any removal by the Board to the plaintiff, in the sense of taking the child against the will of the mother. The plaintiff was taken into the AWB's control because the mother did not want the child, could not keep the child and asked the AWB to take control of her: see s 7(2)': Williams, [26].

60 Williams $v$ The Minister Aboriginal Land Rights Act 1983 and New South Wales [2000] NSWCA 255 at [58].

61 Quoted in Annie White, 'Joy Williams loses her Stolen Generations Case', The World Today: ABC Local Radio, 26 August 1999, http://www.abc.net.au/worldtoday/stories/s46829.htm accessed on l October 2011. 62 Chris Cuneen and Julia Grix, The Limitations of Litigation in the Stolen Generations Cases (Canberra: AIATSIS Research and Discussion Paper, no. 15, 2004): 24. 
release the child from foster care. This presumes that she was an informed liberal subject who had the capacity to pursue this avenue. It discounts the power of the state over Aboriginal people. The court stated:

I further find as a fact that the plaintiff's mother at no time between 1942 and 1960 made application to the [Board] or, otherwise sought to have the plaintiff released from the [Board's] control, or sought her restoration to her care within the meaning of ... the Act, nor was any discharge of the plaintiff sought at any time pursuant to ... the Act.

... [This] is consistent with a view that she did not wish the child's status or relationship viz the Board to change ... nor did she wish to have the child returned to her care. ${ }^{63}$

\section{False imprisonment in Lampard-Trevorrow}

When false imprisonment was argued by Bruce Trevorrow, the Supreme Court of South Australia at trial accepted this on the basis that there was no parental or child consent. The court held:

By being placed with [his foster mother], the plaintiff's will was completely overborne. Given the plaintiff's age at the time of the removal, he did not consent; neither did his parents. The plaintiff was imprisoned, and the State, through its agents and emanations, caused the imprisonment. ${ }^{64}$

However, the South Australian Court of Appeal in Lampard-Trevorrow overturned this finding through a narrow reading of 'imprisonment', which is anomalous to the broad contextual approach it took to other aspects of its reasoning - including consent. It held that the care and protection given by the carer of a child is not a deprivation of the child's liberty. The court of appeal reasoned that Bruce Trevorrow 'was able to move about (once he reached a certain age) as he wished subject only to the normal limits placed on children' and was 'not imprisoned within a defined area' by his foster parents beyond the normal control of parents. ${ }^{65}$ The bench stated:

It might be added that if this is a case of total restraint or total deprivation of freedom of movement, then all small children are, as a matter of

63 Williams, [179].

64 Trevorrow, 982.

65 Lampard-Trevorrow, 284. 
fact, equally subject to the same restraint. ... Bruce Trevorrow, when fostered by Mrs Davies, had the same freedom of movement, or absence of freedom as the case may be, as other children of a like age. ${ }^{66}$

The court did not appreciate that non-Aboriginal children of Bruce Trevorrow's age would have had the freedom to be with their parents. It is only because of the policy of the Stolen Generations that Trevorrow was denied this freedom. The court drew unfitting analogies with restraint in childcare centres, stating, 'Most childcare centres have substantial fences and a gate that children cannot open' ${ }^{67}$ In this acontextual reading, the court was not addressing the liberty denied to Bruce Trevorrow to be with his parents due to the policy of Aboriginal child removal. In other words, an Aboriginal child's forcible restraint from his parents and against his parents' wishes was regarded as the same as a nonAboriginal person who lived with his parents and was not subject to the Stolen Generations policy.

\section{Conclusion}

Consent generally implies an autonomous liberal agent who is invariably a white upper-class adult. The implications of this model do not auger well for Aboriginal subjects who do not have agency within a coercive policy of child removal. Nonetheless, the consent of the Aboriginal mother is referred to continuously by the state in attempting to defeat Stolen Generations cases. It was a powerful justification for the policy of removal, suggesting that not only did white officials and missionaries believe that removal was good for Aboriginal children, but so did their parents.

However, the historical record problematises the historical operation of Aboriginal consent in child removal. In Cubillo, the court alludes to these problems but it does not ultimately support the Aboriginal version of coerced consent or rely on it to affect the interpretation of the law underpinning removals. Justice Atkinson criticised the courts in Williams and Cubillo for not giving 'adequate recognition to the social and historical context of removal' in addressing the issue of consent. ${ }^{68}$

By contrast, the court in Lampard-Trevorrow explicitly acknowledged the problems with consent and this had legal effect. However, the court stopped short of recognising that non-consent to removal was a form of restraint on

\footnotetext{
66 ibid., 285.

67 ibid., 298.

68 The Hon Justice Roslyn Atkinson, ‘Denial and Loss: Removal of Indigenous Australian Children from their Families and Culture', QUT Law and Justice Journal 5, no. 1 (2005): np, http://www.law.qut.edu.au/ljj/ editions/v5n1/atkinson_full.jsp accessed on 1 October 2011.
} 
the child, that is, a restraint to be with his or her parents. Ann Curthoys, Ann Genovese and Alexander Reilly in their book Rights and Redemption: History, Law and Indigenous People discuss the increasing role of historians as experts in indigenous litigation involving historical wrongs. They point to the importance of the disciplines of law and history to talk to one another in these cases. ${ }^{69}$ The expertise of historians was drawn on, across the Stolen Generations cases discussed. It is only in Lampard-Trevorrow, however, that a contextualised historical understanding has legal effect. There we begin to see a true marriage of law and history. It is yet to be seen whether, in future cases, there will be a more contextual understanding of consent.

Our analysis of the narratives in Stolen Generations cases reveals deep tensions in the ways consent arises: the ways in which consent does and does not matter; and the ways in which, as narratives and legal issues become focalised through consent, counter-narratives arise that challenge the interpretation of consent. Trevorrow and Lampard-Trevorrow go some way to show the operation of consent institutionally in the removal of children - particularly the South Australian Supreme and appeal courts' selection/acceptance of evidence, which relies on an understanding of the institutional power that 'produced' consent and disguised both the state's coercion and families' resistance. The facts in Lampard-Trevorrow were held to indicate the absence of consent - in part this was due to the court's practices of interpretation, which acknowledged a different kind of history and evidence from early cases, but this was also partly due to Bruce Trevorrow's experience, which made him in many ways an ideal plaintiff'.$^{70}$ For mothers who gave their consent to the removal of their children, who were without choice or recourse in handing over consent, there continues to be no remedy.

The case leaves open a number of questions about how the legal narrative will continue to engage with historical accounts. Could future cases allow a claim in which formal consent is present, thus acknowledging the problematic operation of consent as a structural, historical practice? Or will Lampard-Trevorrow be confined to an exceptional status? How would Topsy's thumbprint be interpreted post-Lampard-Trevorrow? We know that, at the moment, litigants in South Australia and elsewhere are lining up to draw on the precedent in LampardTrevorrow. If the effect of Lampard-Trevorrow in future cases is to disavow the operation of meaningful consent in the context of Stolen Generations removals, this would go a long way in providing meaningful legal outcomes for Aboriginal plaintiffs. Under such an approach, the formal consent of Topsy's thumbprint

69 Ann Curthoys, Ann Genovese and Alexander Reilly, Rights and Redemption: History, Law and Indigenous People (Sydney: UNSW Press, 2008), 223-24.

70 Antonio Buti, 'The Stolen Generations Litigation Revisited', Melbourne University Law Review 32, no. 2 (2008): 420 . 
would be interpreted in the context of its historical production, and doubted as evidence of meaningful consent. A significant test will be how future courts confront documentary evidence of consent and how they handle competing historical evidence of the lack of choice facing an Aboriginal mother. LampardTrevorrow provides precedent for a more contextualised understanding of the removal of children. The courts, however, cannot be complacent about the legal discipline's role in addressing these matters, and will continue to need to rely on historians to unveil consent as a tool of disguise and a technique of force in particular circumstances. 